\title{
Geobacter uraniireducens sp. nov., isolated from subsurface sediment undergoing uranium bioremediation
}

\author{
Evgenya S. Shelobolina, ${ }^{1} \dagger$ Helen A. Vrionis, ${ }^{1}$ Robert H. Findlay ${ }^{2}$ \\ and Derek R. Lovley ${ }^{1}$ \\ ${ }^{1}$ Department of Microbiology, University of Massachusetts, Morrill Science Center IVN, Amherst, \\ MA 01003, USA \\ ${ }^{2}$ Department of Biological Sciences, University of Alabama, Box 870206, Tuscaloosa, \\ AL 35487-0206, USA
}

Correspondence

Evgenya S. Shelobolina shelobolina@wisc.edu

\begin{abstract}
A Gram-negative, rod-shaped, motile bacterium, strain $\mathrm{Rf}^{\top}{ }^{\top}$, which conserves energy from dissimilatory $\mathrm{Fe}$ (III) reduction concomitant with acetate oxidation, was isolated from subsurface sediment undergoing uranium bioremediation. The $16 \mathrm{~S}$ rRNA gene sequence of strain Rf4 ${ }^{\top}$ matched sequences recovered in 16S rRNA gene clone libraries constructed from DNA extracted from groundwater sampled at the same time as the source sediment. Cells of strain $\mathrm{Rf} 4^{\top}$ were regular, motile rods, $1.2-2.0 \mu \mathrm{m}$ long and 0.5-0.6 $\mu \mathrm{m}$ in diameter, with rounded ends. Cells had one lateral flagellum. Growth was optimal at $\mathrm{pH} 6.5-7.0$ and $32{ }^{\circ} \mathrm{C}$. With acetate as the electron donor, strain $\mathrm{Rf} 4^{\top}$ used $\mathrm{Fe}(\mathrm{III}), \mathrm{Mn}(\mathrm{IV})$, anthraquinone-2,6-disulfonate, malate and fumarate as electron acceptors and reduced $\mathrm{U}(\mathrm{VI})$ in cell suspensions. With poorly crystalline $\mathrm{Fe}(\mathrm{III})$ oxide as the electron acceptor, strain $\mathrm{Rf}^{\top}{ }^{\top}$ oxidized the following electron donors: acetate, lactate, pyruvate and ethanol. Phylogenetic analysis of the $16 \mathrm{~S}$ rRNA gene sequence of strain Rf4 ${ }^{\top}$ placed it in the genus Geobacter. Strain Rf4 ${ }^{\top}$ was most closely related to 'Geobacter humireducens' JW3 (95.9\% sequence similarity), Geobacter bremensis Dfr $1^{\top}$ (95.4\%) and Geobacter bemidjiensis Bem ${ }^{\top}$ (95.1\%). Based on phylogenetic analysis and phenotypic differences between strain $\mathrm{Rf} 4^{\top}$ and closely related Geobacter species, this strain is described as a representative of a novel species, Geobacter uraniireducens sp. nov. The type strain is Rf4 ${ }^{\top}\left(=\right.$ ATCC BAA-1134 $\left.{ }^{\top}=\mathrm{JCM} 13001^{\top}\right)$.
\end{abstract}

Geobacter species are Gram-negative bacteria of the family Geobacteraceae within the class Deltaproteobacteria. Based on phylogenetic analysis of conserved genes (nifD, $\operatorname{rec} A, \operatorname{gyr} B$, $r p o B$ and $f u s A$ ), members of the family Geobacteraceae have been grouped into three phylogenetic clusters: Geobacter, Desulfuromonas and Desulfuromusa (Holmes et al., 2004). The Geobacter cluster hosts freshwater mesophilic dissimilatory iron-reducing bacteria (DIRB) of the genus Geobacter that are capable of complete oxidation of acetate and other multi-carbon organic substrates to carbon dioxide. Microorganisms of the Desulfuromonas cluster are capable of growth in marine media and include psychrophilic, mesophilic and thermophilic DIRB of the genera Desulfuromonas, Geoalkalibacter and Geothermobacter

tPresent address: Department of Geology and Geophysics, University of Wisconsin-Madison, 1215 W. Dayton St. A362, Madison, WI 53706, USA.

Abbreviations: AQDS, anthraquinone-2,6-disulfonate; DIRB, dissimilatory iron-reducing bacteria.

The GenBank/EMBL/DDBJ accession number for the $16 \mathrm{~S}$ rRNA gene sequence of Geobacter uraniireducens strain Rf4 $4^{\top}$ is EF527427.
(Holmes et al., 2004; Zavarzina et al., 2006; Vandieken et al., 2006). The Desulfuromusa cluster contains $S^{0}$ - and $\mathrm{Fe}(\mathrm{III})$-reducing psychrophilic and mesophilic Desulfuromusa, Malomonas and Geopsychrobacter species (Holmes et al., 2004; Vandieken et al., 2006). Species of the genus Pelobacter are scattered through all three phylogenetic clusters of the Geobacteraceae. With one exception, the members of this genus have a primarily fermentative metabolism and can grow in syntrophic association with methanogens (Schink \& Pfennig, 1982; Schink \& Stieb, 1983; Schink, 1984, 1985). The recently isolated Pelobacter seleniigenes can grow via complete oxidation of acetate to carbon dioxide with selenate, $S^{0}, \mathrm{Fe}$ (III), fumarate, anthraquinone-2,6-disulfonate (AQDS) and nitrate serving as electron acceptors and also via fermentation of pyruvate, citrate and lactate (Narasingarao \& Häggblom, 2007).

Geobacter strains are often the dominant members of subsurface sediments under metal-reducing conditions (Lovley et al., 2004). The goal of this isolation effort was to recover an environmentally relevant Geobacter strain from subsurface sediments undergoing in situ uranium bioremediation. The 
criterion for relevancy was that the $16 \mathrm{~S}$ rRNA gene sequence of the isolate should match the sequence(s) in a $16 \mathrm{~S}$ rRNA gene clone library derived from the same source at the same time. Source sediment for isolation was collected in September 2002 during the third month of acetate injection into the subsurface at the Old Rifle uranium bioremediation field site (Anderson et al., 2003). The PO5 core section from depth $4.5 \mathrm{~m}$ was used for isolation.

To recover Geobacter strains, a direct isolation approach without an enrichment step was chosen. Direct isolation avoids overgrowth of micro-organisms that grow rapidly in laboratory media, but are minor constituents in the environment. Isolate $\mathrm{Rf} 4^{\mathrm{T}}$ was recovered using a roll-tube method (Hungate, 1969). BBL agar (1.5\%; Becton Dickinson) was the solidifying agent. An inoculum $(1 \mathrm{ml})$ from 10 -fold serial dilutions of sediment in a liquid FW (freshwater) medium (Lovley \& Phillips, 1988) was added to $27 \mathrm{ml}$ pressure tubes containing $7 \mathrm{ml}$ melted medium and the pressure tubes were rolled with a tube spinner (Bellco Glass). Acetate $(20 \mathrm{mM})$ served as the electron donor and clay size fraction minerals from the site ( $5 \%$ by wt) served as the source of Fe(III). The clay size fraction minerals were isolated from background Rifle sediment (core PO1) (Chandler et al., 2006) as described previously (Shelobolina et al., 2004). Roll-tubes were incubated vertically at $16{ }^{\circ} \mathrm{C}$, the groundwater temperature. Strain $\mathrm{Rf} 4^{\mathrm{T}}$ was recovered from an individual colony in the last positive dilution $\left(10^{5}\right)$ roll-tube. The colony was transferred to a pressure tube with $2 \mathrm{ml}$ liquid $\mathrm{FW}$ medium containing $20 \mathrm{mM}$ acetate as the electron donor and poorly crystalline Fe(III) oxide (100 mmol $\mathrm{l}^{-1}$ ) (Lovley \& Phillips, 1986) as the electron acceptor. Purity of the culture was checked microscopically and by DNA analysis after growing the culture in medium with yeast extract.

DNA was extracted from strain Rf4 ${ }^{\mathrm{T}}$ using the FastDNA SPIN kit (Bio 101). The 16S rRNA gene was amplified as described previously (Shelobolina et al., 2007b). The 16S rRNA gene sequence of strain $\mathrm{Rf}^{\mathrm{T}}$ had $97.3-99.2 \%$ similarity to Geobacter sequences 14o40, 27o254 and 340239 found in a 16S rRNA gene clone library from groundwater taken at the same time as the source sediment (Fig. 1). Phylogenetic analysis of the 16S rRNA gene sequence of strain $\mathrm{Rf} 4^{\mathrm{T}}$ confirmed that it belongs to the Geobacteraceae (Fig. 1). Strain Rf4 ${ }^{\mathrm{T}}$ was most similar to 'Geobacter humireducens' JW3 (95.9\% sequence similarity), Geobacter bremensis Dfr $1^{\mathrm{T}}$ (95.4\% sequence similarity) and Geobacter bemidjiensis $\mathrm{Bem}^{\mathrm{T}}$ (95.1\% sequence similarity). The DNA G $+\mathrm{C}$ content of strain $\mathrm{Rf}^{\mathrm{T}}$ was $54 \mathrm{~mol} \%$, determined by total genome analysis courtesy of the DOE Joint Genome Institute (http://genome.jgi-psf.org/ finished_microbes/geour/geour.home.html).

Physiological characteristics were determined by previously described methods (Shelobolina et al., 2007b). Results are given in the species description. The phenotypic differences between strain $\mathrm{Rf} 4^{\mathrm{T}}$ and closely related Geobacter species are listed in Table 1. Unlike other described Geobacter species, cells of strain $\mathrm{Rf}^{\mathrm{T}}{ }^{\mathrm{T}}$ had two to four very long flagella (up to $16 \mu \mathrm{m}$ long) (Fig. 2). Cell suspension experiments were carried out as described previously (Shelobolina et al., 2007a). U(VI)-reducing activity of strain $\mathrm{Rf}^{\mathrm{T}}{ }^{\mathrm{T}}$ was $0.18 \mu \mathrm{mol} \mathrm{U}(\mathrm{VI})\left(\mathrm{mg}\right.$ protein) ${ }^{-1} \mathrm{~min}^{-1}$, which is comparable to the $\mathrm{U}(\mathrm{VI})$-reducing activity of Geobacter sulfurreducens (Shelobolina et al., 2007a).

The fatty acid contents of strain Rf4 ${ }^{\mathrm{T}}$ and strains of two closely related Geobacter species, G. bemidjiensis $\mathrm{Bem}^{\mathrm{T}}$ and 'G. humireducens' JW3, were determined after growth with acetate as the electron donor and fumarate as the electron acceptor. Independent triplicate cultures of each strain were grown under identical conditions, washed and lyophilized and whole-cell fatty acid profiles were determined following standard protocols (Sasser, 1990). The whole-cell fatty acid profile of strain $\mathrm{Rf}^{\mathrm{T}}$ comprised mainly straight-chain, even-numbered fatty acids, several branched, odd-chain fatty acids, and several hydroxy fatty acids (Table 2). The four most abundant fatty acids were $16: 1 \omega 7 c, 16: 0$, i15:0 and $14: 0$.

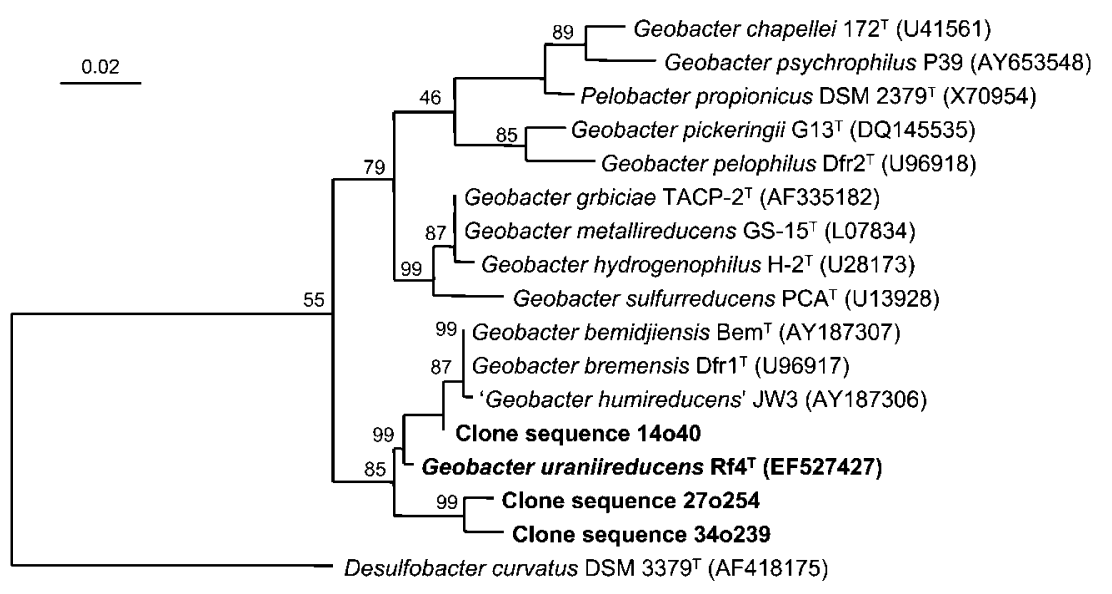

Fig. 1. Neighbour-joining phylogenetic tree with Jukes-Cantor correction based on $16 \mathrm{~S}$ rRNA gene sequences. The tree, which was generated using the ARB software environment (http://www.arb-home.de), shows the relationships between strain $\mathrm{Rf}^{\top}{ }^{\top}$ and related members of the family Geobacteraceae. Desulfobacter curvatus DSM $3379^{\top}$ was used as the outgroup. The shorter environmental clone sequences (448 bases; not deposited in GenBank) were recovered from groundwater sampled at the same time as the source sediment for strain $\mathrm{Rf}_{4}{ }^{\top}$ isolation. Bootstrap values (\%) from 1000 iterations are shown at nodes. Bar, 2 substitutions per 100 nucleotide positions. 
Table 1. Properties of strain Rf $4^{\top}$ and type strains of closely related Geobacter species and the type species, Geobacter metallireducens

All tests were performed under comparable conditions. Strains: 1, Geobacter uraniireducens sp. nov. $\mathrm{Rf}^{\mathrm{T}}{ }^{\mathrm{T}}$ (data from this study); 2 , 'G. humireducens' JW3 (Coates et al., 1998); 3, G. bremensis Dfr $1^{\mathrm{T}}$ (Straub et al., 1998; Straub \& Buchholz-Cleven, 2001); 4, G. bemidjiensis Bem ${ }^{\mathrm{T}}$ (Nevin et al., 2005); 5, G. metallireducens GS-15 ${ }^{\mathrm{T}}$ (Lovley et al., 1993). For strain $\mathrm{Rf}^{\mathrm{T}}$, electron acceptors were tested with acetate as the electron donor and electron donors were tested with poorly crystalline $\mathrm{Fe}(\mathrm{III})$ oxide as the electron acceptor. +, Positive; -, negative, ND, no data available.

\begin{tabular}{|lccccc|}
\hline Characteristic & $\mathbf{1}$ & $\mathbf{2}$ & $\mathbf{3}$ & $\mathbf{4}$ & $\mathbf{5}$ \\
\hline DNA G+C content $(\mathrm{mol} \%)$ & 54 & $\mathrm{ND}$ & 60 & 60.9 & 56.6 \\
Optimal temperature $\left({ }^{\circ} \mathrm{C}\right)$ & 32 & 30 & $30-32$ & 30 & $30-35$ \\
Electron acceptors & & & & & \\
$\quad$ Ferric citrate & - & + & $\mathrm{ND}$ & + & + \\
Elemental sulfur & - & + & + & - & - \\
Nitrate & - & + & - & - & + \\
Malate & + & - & + & + & $\mathrm{ND}$ \\
Fumarate & + & + & + & + & - \\
Electron donors & & & & & \\
Lactate & + & + & + & + & - \\
H & - & + & + & + & - \\
Formate & - & + & + & - & - \\
Propionate & - & - & + & + & + \\
Butyrate & - & - & + & + & + \\
Valerate & - & $\mathrm{ND}$ & - & + & + \\
Succinate & - & - & + & + & $\mathrm{ND}$ \\
Butanol & - & $\mathrm{ND}$ & + & + & + \\
& & & & & \\
\hline
\end{tabular}

Based on phenotypic and genotypic differences between strain $\mathrm{Rf} 4^{\mathrm{T}}$ and other Geobacter species (Tables 1 and 2, Fig. 1), it is suggested that this isolate represents a novel species, Geobacter uraniireducens sp. nov.

\section{Description of Geobacter uraniireducens sp. nov.}

Geobacter uraniireducens (u.ra.ni.i.re.du'cens. N.L. n. uranium uranium; L. part. adj. reducens leading back, bringing back and, in chemistry, converting to a reduced oxidation state; N.L. part. adj. uraniireducens reducing uranium).
Table 2. Whole-cell fatty acid compositions of $G$. uraniireducens sp. nov. Rf4', G. bemidjiensis $\mathrm{Bem}^{\top}$ and 'G. humireducens' JW3

Data are presented as means $\pm \mathrm{SD}(n=3)$ of total fatty acids (percentages by weight); -, fatty acid not found; tr, present at less than $1 \%$ of total fatty acids. Fatty acids were identified by co-elution with known standards and MS analysis. Fatty acids are listed in order of elution on a DB-1 column and named using the format $x: y \omega z$, where $x$ is the number of carbons in the molecule, $y$ is the number of double bonds present and $z$ is the position of the double bound in reference to the aliphatic or ' $\omega$ ' end of the molecule. i, iso branching pattern; a, anteiso branching pattern; br, unknown branching pattern; 3 -OH, $\beta$-hydroxy fatty acid. MS analysis suggests that UNK 1 is probably a summed feature of branched, unsaturated 15-carbon fatty acids; its equivalent chain length (ECL) is 14.32 . The mass spectrum of UNK 2 (ECL 16.15) has a base peak typical of a 3-OH fatty acid $(\mathrm{m} / \mathrm{z} 103)$, but its ECL is inconsistent with any known straight-chain, saturated $\beta$-hydroxy fatty acid.

\begin{tabular}{|c|c|c|c|}
\hline Fatty acid & $R f 4^{T}$ & $\begin{array}{c}\text { G. bemidjiensis } \\
\text { Bem }^{\mathrm{T}}\end{array}$ & $\begin{array}{c}\text { 'G. humireducens' } \\
\text { JW3 }\end{array}$ \\
\hline $12: 0$ & - & $\operatorname{tr}$ & $\operatorname{tr}$ \\
\hline $13: 0$ & $\operatorname{tr}$ & $\operatorname{tr}$ & $\operatorname{tr}$ \\
\hline $14: 1$ & $2.16 \pm 0.03$ & $\operatorname{tr}$ & $\operatorname{tr}$ \\
\hline $14: 0$ & $10.20 \pm 0.25$ & $4.64 \pm 0.67$ & $6.58 \pm 0.93$ \\
\hline UNK 1 & $3.63 \pm 0.017$ & $1.11 \pm 0.15$ & $2.67 \pm 0.34$ \\
\hline i15:0 & $11.46 \pm 0.49$ & $15.01 \pm 0.82$ & $12.25 \pm 0.77$ \\
\hline a15:0 & $\operatorname{tr}$ & $\operatorname{tr}$ & $\operatorname{tr}$ \\
\hline $15: 1$ & - & $\operatorname{tr}$ & $\operatorname{tr}$ \\
\hline $15: 0$ & $3.43 \pm 0.02$ & $3.99 \pm 1.06$ & $3.99 \pm 0.15$ \\
\hline $\begin{array}{r}3-\mathrm{OH} \\
14: 0\end{array}$ & $\operatorname{tr}$ & $\operatorname{tr}$ & $1.68 \pm 0.08$ \\
\hline $16: 1 \omega 7$ & $26.06 \pm 0.71$ & $31.06 \pm 0.83$ & $29.67 \pm 1.41$ \\
\hline $16: 1 \omega 5$ & $1.16 \pm 0.02$ & $1.82 \pm 0.07$ & $2.57 \pm 0.11$ \\
\hline $16: 0$ & $21.50 \pm 0.12$ & $20.53 \pm 0.41$ & $19.46 \pm 0.98$ \\
\hline UNK 2 & $6.70 \pm 0.75$ & $6.57 \pm 1.10$ & $7.11 \pm 0.55$ \\
\hline br17: 1 & $5.82 \pm 0.10$ & $10.99 \pm 1.09$ & $7.23 \pm 1.39$ \\
\hline a17: $1 \omega 6$ & - & $\operatorname{tr}$ & - \\
\hline a17: 0 & - & $\operatorname{tr}$ & - \\
\hline $\begin{array}{r}3-\mathrm{OH} \\
16: 0\end{array}$ & $5.17 \pm 0.028$ & $\operatorname{tr}$ & $3.64 \pm 0.93$ \\
\hline $18: 1 \omega 7$ & $1.23 \pm 0.45$ & $\operatorname{tr}$ & $1.15 \pm 0.07$ \\
\hline $18: 0$ & $1.04 \pm 0.38$ & $1.08 \pm 0.84$ & $\operatorname{tr}$ \\
\hline
\end{tabular}

(a)

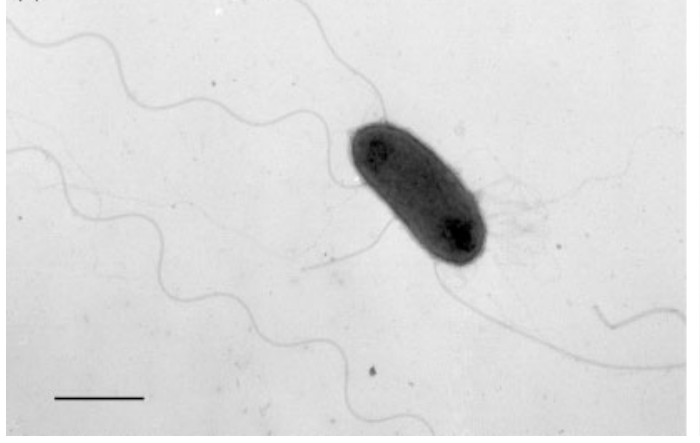

(b)

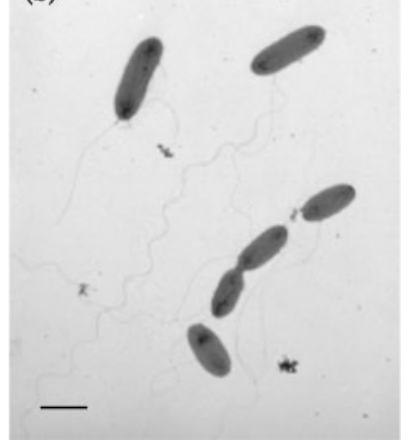

Fig. 2. Morphology of negatively stained cells of $\mathrm{Rf}^{\top}$. Strain $\mathrm{Rf} 4^{\top}$ was grown with acetate as the electron donor and fumarate as the electron acceptor. Cells were harvested in the middle of the exponential growth phase. Cells exhibit long pili and tubular projections (blebs) on the cell surface (a) as well as long flagella (b). Bars, $1 \mu \mathrm{m}$. 
Cells are Gram-negative, motile, regular or slightly curved rods, $1.2-2.0 \mu \mathrm{m}$ long and $0.5-0.6 \mu \mathrm{m}$ in diameter. When grown on $20 \mathrm{mM}$ fumarate $/ 10 \mathrm{mM}$ acetate or $20 \mathrm{mM}$ malate $/ 10 \mathrm{mM}$ acetate medium, cells have two to four flagella (up to $16 \mu \mathrm{m}$ long), pili and vesicles. On $20 \mathrm{mM}$ fumarate $/ 10 \mathrm{mM}$ acetate medium, growth is most rapid at $\mathrm{pH}$ 6.5-7.0; no growth is observed below $\mathrm{pH} 6.0$ or above $\mathrm{pH}$ 7.7. Optimal growth is at $32{ }^{\circ} \mathrm{C}$; no growth is observed at initial temperatures lower than $10{ }^{\circ} \mathrm{C}$ or higher than $34{ }^{\circ} \mathrm{C}$. With $100 \mathrm{mmol}$ poorly crystalline $\mathrm{Fe}(\mathrm{III})$ oxide $\mathrm{l}^{-1}$ as electron acceptor, the following electron donors are utilized: acetate, lactate, pyruvate and ethanol. Hydrogen $\left(\mathrm{H}_{2} / \mathrm{CO}_{2}\right.$; $80: 20, \mathrm{v} / \mathrm{v}$ ), formate, methanol, butanol, butyrate, valerate, propionate, succinate and citrate are not utilized as electron donors. With $20 \mathrm{mM}$ acetate, the following electron acceptors are utilized: poorly crystalline $\mathrm{Fe}(\mathrm{III})$ oxide, ferruginous smectite SWa-1, $\mathrm{Fe}(\mathrm{III})$ nitrilotriacetate, $\mathrm{Fe}(\mathrm{III})$ pyrophosphate, birnessite $(\mathrm{MnOOH}), \mathrm{AQDS}$, malate and fumarate. Oxygen, $\mathrm{Fe}(\mathrm{III})$ citrate, sulfate, sulfite, thiosulfate, elemental sulfur and nitrate are not utilized as electron acceptors. Cell suspensions reduce U(VI). The major fatty acids are $16: 1 \omega 7 c, 16: 0, \mathrm{i} 15: 0$ and $14: 0$.

The type strain is $\mathrm{Rf}^{\mathrm{T}}$ (=ATCC BAA- $1134^{\mathrm{T}}=\mathrm{JCM}$ $\left.13001^{\mathrm{T}}\right)$, isolated from subsurface sediment undergoing uranium bioremediation. The DNA $\mathrm{G}+\mathrm{C}$ content of the type strain is $54.0 \mathrm{~mol} \%$.

\section{Acknowledgements}

We would like to thank R. T. Anderson for obtaining the sediment sample from the Old Rifle site in Rifle, CO, USA. This research was supported by the Office of Science (BER), US Department of Energy, grant nos DE-FC02-02ER63466 and DE-FG02-97ER62475.

\section{References}

Anderson, R. T., Vrionis, H. A., Ortiz-Bernad, I., Resch, C. T., Long, P. E., Dayvault, R., Karp, K., Marutzky, S., Metzler, D. R. \& other authors (2003). Stimulating the in situ activity of Geobacter species to remove uranium from the groundwater of a uranium-contaminated aquifer. Appl Environ Microbiol 69, 5884-5891.

Chandler, D. P., Jarrell, A. E., Roden, E. R., Golova, J., Chernov, B., Schipma, M. J., Peacock, A. D. \& Long, P. E. (2006). Suspension array analysis of $16 \mathrm{~S}$ rRNA from $\mathrm{Fe}$ - and $\mathrm{SO}_{4}^{2-}$-reducing bacteria in uranium-contaminated sediments undergoing bioremediation. Appl Environ Microbiol 72, 4672-4687.

Coates, J. D., Ellis, D. J., Roden, E., Gaw, K., Blunt-Harris, E. L. \& Lovley, D. R. (1998). Recovery of humics-reducing bacteria from a diversity of sedimentary environments. Appl Environ Microbiol 64, 1504-1509.

Holmes, D. E., Nevin, K. P. \& Lovley, D. R. (2004). Comparison of $16 \mathrm{~S}$ rRNA, nifD, $r e c A, \operatorname{gyr} B, \operatorname{rpoB}$ and fusA genes within the family Geobacteraceae fam. nov. Int J Syst Evol Microbiol 54, 1591-1599.

Hungate, R. E. (1969). A roll tube method for cultivation of strict anaerobes. Methods Microbiol 3B, 117-132.

Lovley, D. R. \& Phillips, E. J. P. (1986). Organic matter mineralization with reduction of ferric iron in anaerobic sediments. Appl Environ Microbiol 51, 683-689.

Lovley, D. R. \& Phillips, E. J. P. (1988). Novel mode of microbial energy metabolism: organic carbon oxidation coupled to dissimilatory reduction of iron or manganese. Appl Environ Microbiol 54, 1472-1480.

Lovley, D. R., Giovannoni, S. J., White, D. C., Champine, J. E., Phillips, E. J. P., Gorby, Y. A. \& Goodwin, S. (1993). Geobacter metallireducens gen. nov. sp. nov., a microorganism capable of coupling the complete oxidation of organic compounds to the reduction of iron and other metals. Arch Microbiol 159, 336-344.

Lovley, D. R., Holmes, D. E. \& Nevin, K. P. (2004). Dissimilatory $\mathrm{Fe}(\mathrm{III})$ and $\mathrm{Mn}(\mathrm{IV})$ reduction. Adv Microb Physiol 49, 219-286.

Narasingarao, P. \& Häggblom, M. M. (2007). Pelobacter seleniigenes sp. nov., a selenate-respiring bacterium. Int J Syst Evol Microbiol 57, 1937-1942.

Nevin, K. P., Holmes, D. E., Woodard, T. L., Hinlein, E. S., Ostendorf, D. W. \& Lovley, D. R. (2005). Geobacter bemidjiensis sp. nov. and Geobacter psychrophilus sp. nov., two novel Fe(III)-reducing subsurface isolates. Int J Syst Evol Microbiol 55, 1667-1674.

Sasser, M. (1990). Identification of bacteria by gas chromatography of cellular fatty acids, MIDI Technical Note 101. Newark, DE: MIDI Inc.

Schink, B. (1984). Fermentation of 2,3-butanediol by Pelobacter carbinolicus sp. nov. and Pelobacter propionicus sp. nov., and evidence for propionate formation from $\mathrm{C}_{2}$ compounds. Arch Microbiol 137, 33-41.

Schink, B. (1985). Fermentation of acetylene by an obligate anaerobe, Pelobacter acetylenicus sp. nov. Arch Microbiol 142, 295-301.

Schink, B. \& Pfennig, N. (1982). Fermentation of trihydroxybenzenes by Pelobacter acidigallici gen. nov. sp. nov., a new strictly anaerobic, non-spore-forming bacterium. Arch Microbiol 133, 195-201.

Schink, B. \& Stieb, M. (1983). Fermentative degradation of polyethylene glycol by a strictly anaerobic, gram-negative, nonsporeforming bacterium, Pelobacter venetianus sp. nov. Appl Environ Microbiol 45, 1905-1913.

Shelobolina, E. S., Anderson, R. T., Vodyanitskii, Y. N., Sivtsov, A. V., Yuretich, R. \& Lovley, D. R. (2004). Importance of clay size minerals for $\mathrm{Fe}(\mathrm{III})$ respiration in a petroleum-contaminated aquifer. Geobiology 2, 67-76.

Shelobolina, E. S., Coppi, M. V., Korenevsky, A. A., DiDonato, L. N., Sullivan, S. A., Konishi, H., Xu, H., Leang, C., Butler, J. E. \& other authors (2007a). Importance of $c$-type cytochromes for U(VI) reduction by Geobacter sulfurreducens. BMC Microbiol 7, 16.

Shelobolina, E. S., Nevin, K. P., Blakeney-Hayward, J. D., Johnsen, C. V., Plaia, T. W., Krader, P., Woodward, T., Holmes, D. E., VanPraagh, C. G. \& Lovley, D. R. (2007b). Geobacter pickeringii sp. nov., Geobacter argillaceus sp. nov. and Pelosinus fermentans gen. nov., sp. nov., isolated from subsurface kaolin lenses. Int J Syst Evol Microbiol 57, 126-135.

Straub, K. L. \& Buchholz-Cleven, B. E. (2001). Geobacter bremensis sp. nov. and Geobacter pelophilis sp. nov., two dissimilatory ferriciron-reducing bacteria. Int J Syst Evol Microbiol 51, 1805-1808.

Straub, K. L., Hanzlik, M. \& Buchholz-Cleven, B. E. (1998). The use of biologically produced ferrihydrite for the isolation of novel ironreducing bacteria. Syst Appl Microbiol 21, 442-449.

Vandieken, V., Mußmann, M., Niemann, H. \& Jørgensen, B. B. (2006). Desulfuromonas svalbardensis sp. nov. and Desulfuromusa ferrireducens sp. nov., psychrophilic, $\mathrm{Fe}$ (III)-reducing bacteria isolated from Arctic sediments, Svalbard. Int J Syst Evol Microbiol 56, $1133-1139$.

Zavarzina, D. G., Kolganova, T. V., Boulygina, E. S., Kostrikina, N. A., Tourova, T. P. \& Zavarzin, G. A. (2006). Geoalkalibacter ferrihydriticus gen. nov. sp. nov., the first alkaliphilic representative of the family Geobacteraceae, isolated from a soda lake. Microbiology (English translation of Mikrobiologiia) 75, 673-682. 